\title{
Chemical Analysis of Ginger Root
}

\author{
${ }^{1}$ Latona D. F., ${ }^{2}$ Oyeleke G. O. ${ }^{3}$ Olayiwola O. A \\ 1,2,3 (OSUN State Polytechnic, Departmnt of Applied Science, \\ Pmb 301 Iree, Nigeria).
}

\begin{abstract}
Ginger root( Zingiber officinal Rose) was analysed to identify its nutritional and anti-nutritional contents. The results showed that Ginger has $34.13 \%$ crude protein, $4.07 \%$ Ether Extract, $4.02 \%$ crude fibre content, $13.75 \%$ moisture content, $7.64 \%$ Ash content and $1.036 \%$ vitamin C. Furthermore, ginger contains major minerals like: Zn $64.0 \mathrm{mg} / \mathrm{l}$, Mn $5.90 \mathrm{mg} / \mathrm{l}$, Fe $279.7 \mathrm{mg} / \mathrm{l}, \mathrm{Cu} 8.80 \mathrm{mg} / \mathrm{l}, \mathrm{Ca} 280.0 \mathrm{mg} / \mathrm{l}$ and P 8068.0 $\mathrm{mg} / \mathrm{l}$. The result obtained confirmed the usefulness of ginger root as a potential functional food and could be explored further in new product and formulation.
\end{abstract}

\section{Introduction}

Ginger (Zingiber officinal rose) is an underground stem or rhizome of the plant Zingiber officinate. It has ben used as traditional medicine in China, India, Malaysia and Arabic countries since ancient times. Ginger has been used to treat stomach upset, nausea, diarrhea, colic, arthritis, heart conditions, flu- like symptoms and painful menstral periods ${ }^{1}$. It was found that Ginger extracts have antimicrobial properties against E.Coli, sslmonella typhi and bacillus substilis that are common cause of gastro intestinal tract infections ${ }^{2}$.

The important active component of ginger root is the volatile oil and pungent phenol compound such as gingerol, which is a very potent anti-inflammatory compound. Mordern scientific research has revealed that ginger possesses numerous therapeutic like anti-oxidant effects, an ability to inhibit the formation of inflammatory compounds and direct anti-inflammatory effects ${ }^{3}$. Ginger has aso been found to reduce all symptoms associated with motion sickness like dizziness, cold sweating, nausea and vomiting ${ }^{4}$.

\section{Materials And Metods}

Ginger root were bought from a local market in Offa, Nigeria. The ginger root used for analysis were fresh without any physical defect. Furthermore, the ginger were surface cleaned and washed in running tap water to remove adhering debris after which the samples were air dried for five days in air dryer and were grinded to fine powder using a commercial blender. The powdered samples were stored at $5^{\circ} \mathrm{Cuntil}$ further analysis.

Air dried ginger samples were analysed for chemical composition at the Obafemi Awolowo University Ile-Ife, Nigeria. Samples were analysed chemically according to official analytical chemist (AOAC) ${ }^{5}$. Analyses were carried out using powdered ginger root and were done in duplicates.

\section{Crude protein determination}

Crude protein in the residue were determined by the routine semi - micro kjeldahl procedure. This consists of three techniques of analysis namely: Digestion, Distillation and Titration.

Distillation was done using Markham Distillation Apparatus which allowed volatile substances such as ammonia to be steam distilled with complete collection of the distillate. $5 \mathrm{ml}$ portion of the digest above was taken into the body of the apparatus via small funnel aperture. Then $3 \mathrm{ml}$ of $40 \%(\mathrm{w} / \mathrm{v}) \mathrm{NaOH}$ was added through the same opening with a $5 \mathrm{ml}$ pipette. The mixture was steam distilled for 2 minutes into a $50 \mathrm{ml}$ conical flask containing $10 \mathrm{ml}$ of $2 \%$ Boric acid mixed indicator solution placed at the receiving tips of the condenser. The Boric acid plus indicator solution changed colour from red to green showing that all the ammonia liberated had been trapped.

Furtermore, digestion was done by taking $0.50 \mathrm{~g}$ of ground dried sample carefully into the kjeldahl digestion tubes to ensure that all samples got to the bottom of the tubes and was added to $10 \mathrm{ml}$ of conc. $\mathrm{H}_{2} \mathrm{SO}_{4}$ which were set in the appropriate hole of the digestion block heater in a fume cupboard. The digestion was left for hours after which a clear colourless solution was left in the tube. The digestion was cooled and carefully transferred into $100 \mathrm{ml}$ volumetric flask and made to mark with distilled water. Consequently, the green colour obtained from distillation was then titrated against $0.01 \mathrm{~N} \mathrm{HCl}$ contained in a burette. At the equivalent point, the green colour turned to wine colour which indicated that all Nitrogen trapped an Ammonium Borate have been removed as Ammonium chloride.

$\% \mathrm{~N}=$ Titre value $\mathrm{x}$ Atomic mass of Nitrogen $\mathrm{x}$ molarity of $\mathrm{HCl} \mathrm{x} 4$

The total crude protein content was determined by multiplying percentage nitrogen by a constant factor of 6.26 .

$\%$ crude protein $=\% \mathrm{~N} \times 6.26$ 


\section{Ether Extract Determination}

$1 \mathrm{gm}$ of dried sample was weighed into the fat free extraction thimble and tightened with cotton wool. The thimble was placed in the extractor and fitted up with refluxed condenser with a $250 \mathrm{ml}$ soxlet flask which has been previously dried in the oven, cooled in the dessicator and weighed. The soxhlet flask was then filled to full capacity with petroleum ether $40^{\circ} \mathrm{C}-60^{\circ} \mathrm{C}$ boilng point and the soxhlet flask. Extraction plus condenser set was placed on the heater, the heater was put on for six hours with constant running water from the tap for condensation of ether vapour. The ether was left to siphon over several times for at least $10-12$ times. Distillation was continued until the flask was practically dry. The flask which contained the fat or oil was detached, its exterior cleaned and dried to a constant weight in an oven. Taken the initial weight of dry soxhlet flask as $\mathrm{W}_{\mathrm{o}}$ and the final weight of oven dried flask + oil/fat as $\mathrm{W}_{1}$

$$
\% \text { fat } / \text { oil }=\underline{\mathrm{W}}_{1}-\frac{\mathrm{W}_{0}}{1} \times 100 \%
$$

\section{Crude fibre determination}

$2 \mathrm{~g}$ of the sample $\left(\mathrm{W}_{1}\right)$ was accurately weighed into the fibre flask and $100 \mathrm{ml}$ of $0.255 \mathrm{~N} \mathrm{H}_{2} \mathrm{SO}_{4}$ was added. The mixture was heated under reflux with the heating mantle. The hot mixture was filtered through a fibre sieve cloth. The difference obtained was thrown off and the residue was returned to the flask to which $100 \mathrm{ml}$ of $0.313 \mathrm{M} \mathrm{NaOH}$ was added and heated under reflux for another one hour. The mixture was filtered through a fibre sieve cloth and $10 \mathrm{ml}$ of acetone was added to dissolve any organic constituent. The residue was washed with $50 \mathrm{ml}$ hot water twice on the sieve cloth before it was finally transferred into the crucible. The crucible and the residue were oven dried at $105^{\circ} \mathrm{C}$ overnight to drive off moisture. The oven dried crucible containing the residue was cooled in a dessicator and later weighed for ashing at $550^{\circ} \mathrm{C}$ for four hours. The crucible containing white and grey ash ( free of carbonaceous material) was cooled in a desicator and weighed to obtain $\mathrm{W}_{2}$. The difference $\mathrm{W}_{1}-\mathrm{W}_{2}$ gave the weight of fibre.

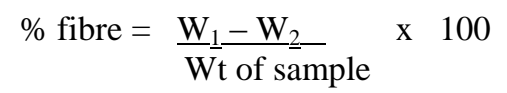

\section{Ash content}

$2 \mathrm{~g}$ of the sample was weighed into porcelain crucible, this was transferred into the muffled furnance at $550^{\circ} \mathrm{C}$ and left for about four hours. About this time it had turned to white ash. The crucible and its content were cooled to about $100^{\circ} \mathrm{C}$ in air then to room temperature in a dessicator and weighed. This was done in duplicate.

\section{Moisture content}

$$
\% \text { Ash content }=\quad \underset{\text { Original wt. of sample }}{\frac{\text { weight of ash }}{\text { a }}} \times 100
$$

$2 \mathrm{~g}$ of the sample was weighed into a previously weighed crucible. The crucible and sample taken were then transferred into the oven set at $100^{\circ} \mathrm{C}$ index and allowed to dry overnight. At the end of the 24 hours the crucible plus sample were removed from the oven and transferred to the dessicator and cooled for 10 minutes and weighed.

Given that,

The weight of empty crucible $=\mathrm{W}_{\mathrm{o}}$

Weight of crucible + sample $=\mathrm{W}_{1}$

Weight of crucible + oven dried sample $=\mathrm{W}_{3}$

$\%$ moisture content $=\underline{\mathrm{W}_{3}}-\underline{\mathrm{W}}_{\underline{\mathrm{O}}} \times 100$

$$
\underline{\mathrm{W}_{1}-} \mathrm{W}_{\mathrm{o}}
$$

\section{Phosphorus determination}

Phosphorus was determined spectrophotometrically. The ash of the sample obtained was treated with $2 \mathrm{M} \mathrm{HCl}$ solution. Consequently, $10 \mathrm{ml}$ of the filtrate solution was pipette into $50 \mathrm{ml}$ standard flask and $10 \mathrm{ml}$ of vanadate yellow solution was added and the flask was made up to mark with distill water, stoppered and left for 10 minutes for full yellow coloration development. The concentration of phosphorus was obtained by taken the optical density or absorbance of the solution on a spectronic 20 spectrophotometer at a wavelength of $470 \mathrm{~nm}$. $\%$ phosphorus $=$ Absobance $\mathrm{x}$ slope $\mathrm{x}$ Dilution factor

$$
10,000
$$

Determination of mineral elements

Determinations of mineral elements were done using Buck 200 atomic absorption spectrophotometer (AAS). 


\section{Result and Discussion}

Proximate composition of the powdered ginger root sample is shown in table I. This shows that crude protein was $34.13 \%$ which is higher than the $12.6 \%$ reported by Bhat et. Al., 2010. The high amount indicate a good source of protein. The crude fibre content was $4.02 \%$ which is ofcourse lower than the $17.6 \%$ reported by an earlier researcher ${ }^{6}$. The crude fibre of the sample was moderate since diet low in fibre is desirable and It may be advantageous as they are known to reduce serium cholesterol levels.

Ether extract content of the sample was $4.07 \%$ and the crude fat content was moderate because samples low in fat is advantageous as they may reduce the risk of coronary heart disease and lower the risk of hypertension. The ash content of the sample was $7.64 \%$, the low ash content indicates the level of essential or non - essential mineral elements in the sample. The moisture content of the sample was $13.75 \%$ which shows that ashing of ginger could be less time consuming.

The mineral elemental composition of ginger root samples as shown in table II indicated that ginger is rich in essential minerals like: calcium $280.0 \mathrm{mg} / 100 \mathrm{~g}$, Iron $279.7 \mathrm{mg} / 100 \mathrm{~g}$, Zinc $64.0 \mathrm{mg} / 100 \mathrm{~g}$, Manganese $5.90 \mathrm{mg} / 100 \mathrm{~g}$ and Copper $8.80 \mathrm{mg} / 100 \mathrm{~g}$. The result on mineral composition are in agreement with an earlier report on some medicinal plant species which showed calcium as the pre-dominant element ${ }^{7}$. It was reported that the dietary intake of essential minerals should be $>50 \mathrm{mg} /$ day. The essential minerals like calcium and phosphorus are important in extra- cellular and intra-cellular body functions and as components responsible for the bulding block of structural component in human body. Minerals like Iron, even if present in threshold level can act as anti-oxidant and are involved in strengthening the immune system. Whereas Zinc are known to prevent cardiomyopathy, muscle degeneration, growth retardation and bleeding disorder. Therefore, the presence of these minerals in ginger root provides bases for their use in food application ${ }^{8}$.

Table I: Proximate composition of ginger root

\begin{tabular}{|l|l|}
\hline Parameter & Amount $(\%)$ \\
\hline Crude protein & 34.13 \\
\hline Crude fat & 4.02 \\
\hline Ether extract & 4.07 \\
\hline Ash content & 7.64 \\
\hline Moisture content & 13.75 \\
\hline Vitamin C & 1.036 \\
\hline
\end{tabular}

Table II: Mineral composition of ginger root

\begin{tabular}{|l|l|}
\hline Parameter & Amount $\mathrm{mg} / 100 \mathrm{~g}$ \\
\hline Zinc & 64.0 \\
\hline Manganese & 5.90 \\
\hline Iron & 279.7 \\
\hline Copper & 8.80 \\
\hline Calcium & 280.0 \\
\hline Phosphorus & 8068.0 \\
\hline
\end{tabular}

\section{Conclusion}

The presence of high amount of fibre content,fat/oil, protein and essential minerals coupled with the therapeutic value of ginger root. It has a wide application in the area of food bio-fortification and for the development of bio-fortified foods. Although ginger root has been used several years as medicinal herb for the treatment of cancer cells and several other therapeutic purposes, it has however been found to be without side effect. Majorly ginger may interfere with blood clothing.

\section{Reference}

1. Altman C.D, Marcussen K.C (2001). Effect of a ginger extract on knee pain in patient with osteoarthritis. Arthritis Rheum, 44(11), 2531- 2538.

2 Chan E.W.C., Lim Y.Y and Omar M (2007) Antioxidant and antibacterial activity of levels of Etlingera species (Zingiberaceae) in peninsular Malaysia. Food Chemistry 104,1586- 1593

3. Thomson M, Al Qattan K.K, Al sawan S.M(2002) The use of ginger( Zingiber officinale rose) as a potential antiflammatory and antithrombotic agent. Prostaglandins Leukot Essent Fatty Acids 67(6), 475-478.

4. Portnoi G, Chig L.A, Karim-Tabesh (2003) Prospective comparative study of the safety and effectiveness of ginger for the treatment of nausea and vomiting in pregnancy. Am J. obstet Gynecol. 189(5), 1374- 1377.

5. AOAC (1990) Official methods of Analysis (15th ed) Washington DC. Association of Analytical chemistry

6. Bhat R., Kiran K., Arun A and Karim A. (2010). Determination of mineral composition and heavy metal content of some nutraceutically valued plant products. Food Analytical methods 3. 181-187.

7. Bhat R and Sridhar K.R (2008) Nutritional quality and evaluation of electron beam-irradiated lotus (Nelumbo nucifera) seed. Food chemistry 107, 174-184.

8. Belitz H.D., Grosch W and Schieberle P (2009) Food chemistry, New-york. Springer pg 1-1070 